\title{
ODUZIMANJE IMOVINSKE KORISTI U KONTEKSTU MEĐUNARODNE PRAVNE STEČEVINE I SUZBIJANJA PODMIĆIVANJA
}

Mijo Galiot, dipl. iur.

zamjenik predsjednika Državnog sudbenog vijeća i

sudac Općinskog suda u Splitu
UDK: 343.352

Ur.: 10. veljače 2017.

Pr.: 14. veljače 2017.

Pregledni znanstveni rad

\section{Sažetak}

Kaznenopravna reakcija na kaznena djela podmićivanja iznimno je važna za svaki uređeni pravni sustav. O uspješnosti te reakcije, a posebno njezina bitnog $i$ neizostavnog segmenta - oduzimanje imovinske koristi, umnogome ovisi cjelokupan politički i gospodarski razvoj pojedine države. Učinkovita primjena instituta (proširenog) oduzimanja imovinske koristi u praksi pokazala se važnom kod kaznenih djela (pasivnog) podmićivanja. Radi se o kaznenim djelima koja podrazumijevaju uspostavu korupcijskog savezu kojem obje strane mogu biti zadovoljne jer ostvaruju određene (imovinske) probitke i koristi.

Kakva će biti kaznenopravna reakcija prema počiniteljima podmićivanja ovisi o stavu društva, točnije, o privremenoj vladajućoj garnituri. O njihovim shvaćanjima, ovisi i kaznenopravna reakcija prema počiniteljima s aspekta oduzimanja imovinske koristi u kaznenim normativima.

U prilog znanstvenoj raspravi, u radu se analizira kaznenopravna mjera oduzimanja imovinske koristi u kontekstu međunarodne pravne stečevine $u$ suzbijanju podmićivanja, uz osvrt na recentnu praksu "uskočkih" sudova. Pritom je naglasak stavljen na prikaz domaće i međunarodne regulacije instituta tzv. proširenog oduzimanja imovinske koristi. Usporednom metodom je dan prikaz i analiza (ne)usklađenosti domaće materijalne regulacije s relevantnom međunarodnom pravnom stečevinom o tom pitanju.

Ključne riječi: korupcija, podmićivanje, imovina, imovinska korist, korist ostvarena kaznenim djelom, oduzimanje imovinske koristi, prošireno oduzimanje imovinske koristi. 


\section{1. $U V O D$}

\subsection{Općenito}

Za problematiku kaznenopravne reakcije na korupcijska ponašanja, pored znanstvene i stručne, zainteresirana je i laička javnost. ${ }^{1}$ Moglo bi se reći da "za korupciju svi znaju da postoji, ali ne znaju točno kako izgleda i kome se daje", ${ }^{2}$ što je upravo čini poluvidljivom i poludohvatljivom pojavom. ${ }^{3}$ Unatoč tomu što svi znaju da je ona nešto u osnovi pogrešno, ovisno o okolnostima, korupcija ima svoje apologete ili progonitelje, što je karakterizira kao tipičnu ambivalentnu pojavu u društvu. ${ }^{4}$ Naime, u odnosu na počinitelje drugih kaznenih djela (primjerice počinitelje kaznenih djela ubojstva, silovanja i dr.), počinitelji korupcijskih kaznenih djela, u slučaju tzv. individualne ili tzv. "ulične" korupcije, ne nailaze na bitniju osudu javnosti, već suprotno, bivaju promatrani kao "sposobni" i "okretni” pojedinci koji se znaju pobrinuti za sebe u grabežljivu društvu u kojem svatko misli samo na sebe i svoje probitke. ${ }^{5} \mathrm{~S}$ druge strane, sistemsku ili državnu korupciju javnost doživljava kao napad na sve pozitivne vrijednosti suvremenog društva, a po viktimološkim kriterijima, žrtvom postaje odnosno smatra se čitavo društvo. ${ }^{6}$

Iako nije jedino sredstvo u sprječavanju i suzbijanju korupcijskih kaznenih djela, kazneno pravo predstavlja vrlo važan i neizostavan segment društvene reakcije na takve pojave. ${ }^{7}$ U tom smislu, Bačić navodi da je suzbijanje korupcije i organiziranog kriminaliteta, kao i kaznenopravne mjere za to, u tom mehanizmu važan čin kaznenog prava. ${ }^{8}$ Kao najvažnije kaznene odredbe tzv. antikorupcijskog kaznenog prava, ističe: inkriminacije o zločinačkoj, kriminalnoj organizaciji, oduzimanju nezakonito stečene (imovinske) koristi, odredbe o pranju novca, odredbe o strožem kažnjavanju članova tih organizacija na više mjesta kod različitih kaznenih djela tipičnih za stil djelovanja tih organizacija, antikorupcijske inkriminacije te odredbe o odgovornosti pravnih osoba. ${ }^{9}$

Institut tzv. proširenog oduzimanja imovine koristi, kao važan dio kaznenopravne reakcije na počinitelje podmićivanja, valja promatrati u kontekstu kameleonske prirode korupcijskih djelovanja. Ova djela često se nazivaju i koluzivnim kaznenim djelima. ${ }^{10}$ Ponajprije stoga što obje strane u korupcijskoj razmjeni mogu biti "zadovoljne" jer ostvaruju određene probitke i koristi, a, drugo, razotkrivanje djela i

1 Slično Datzer, D., Vujović S., Kaznena politika za korupcijska kaznena djela na području kantona Sarajevo, Kriminologija i socijalna integracija, 2013., str. 1.

2 Derenčinović, D., Kaznenopravni aspekti korupcije s elementom inozemnosti, Hrvatski ljetopis za kazneno pravo i praksu, 1999., str. 156.

3 Ibidem.

4 Slično ibidem.

5 Slično Saračević, A., Korupcijska kaznena djela, Hrvatska pravna revija, 2008., str. 82.

6 Ibidem bilj. 2 (Derenčinović, 1999.).

7 Tako, Bačić, F., Korupcija i antikorupcijsko kazneno pravo, Hrvatski ljetopis za kazneno pravo i praksu, 2000., str. 830.

8 Ibidem.

9 Ibidem.

10 Tako i Derenčinović, D., Mit(o) korupciji, Nocci, Zagreb, 2001., str. 267. 
njegovo prijavljivanje može dovesti do samoinkriminiranja, odnosno okolnosti da se protiv prijavitelja pokrene kazneni postupak i da na kraju bude osuđen. ${ }^{11}$ Naime, kako ističe Derenčinović12 , to "nisu djela koja se čine pred svjedocima, materijalni tragovi izuzetno su rijetki zbog transakcija koje više nisu tradicionalne, već sve više postaju distancijskim, a gotovina je sve rjeđe objekt takvih transakcija".

\subsection{Cilj istraživanja}

Kakva će biti kaznenopravna reakcija prema počiniteljima podmićivanja ovisi o stavu pojedinog društva. O tomu ovisi i kaznenopravna reakcija, pa i pitanje njezina važnog i neizostavnog segmenta - oduzimanja imovinske koristi, sadržane u kaznenim pravilima.

Temeljni cilj autora bio je dati pregled i analizu pozitivnih normi, kao dijela kaznenoga materijalnog zakonodavstva, kojima je uređeno oduzimanje imovinski koristi.

Unutar provedenog istraživanja, u prilog znanstvenoj raspravi, u radu se analizira kaznenopravna mjera oduzimanja imovinske koristi u kontekstu međunarodne pravne stečevine o suzbijanja (aktivnog i pasivnog) podmićivanja, uz osvrt na recentnu praksu tzv. uskočkih sudova. Pritom je naglasak stavljen na prikaz domaće i međunarodne regulacije instituta tzv. proširenog oduzimanja imovinske koristi. Usporednom je metodom dan prikaz i analiza (ne)usklađenosti domaće regulacije s relevantnom međunarodnom pravnom stečevinom.

\section{ODUZIMANJE IMOVINSKE KORISTI U KONTEKSTU MEDUNARODNE PRAVNE STEČEVINE}

\subsection{Uvodno}

Zemlje u tranziciji, u koje spada i Hrvatska, posebno su osjetljive na podmićivanje zbog toga što su formalno prošle, a sadržajno i dalje prolaze kroz stadij institucionalnog i normativnog restrukturiranja, u kojem dolazi do bitnih promjena u pravilima ponašanja u okviru pravnog, političkog i gospodarskog sustava tih zemalja. Te države u uvjetima nedostatka tradicije, koja bi učinkovito štitila integritet i konzistentnost institucija bez korupcije te niskog stupnja demokratske kulture, kao i postojanja "neizgrađenih" novih institucija, nisu mogle same riješiti problem korupcije tako da se ta "bolest društva" svede na razinu incidentne korupcije, koja bi bila višemanje kontrolirana. Nužna je bila pomoć međunarodnih institucija i mehanizama u vidu implementacije međunarodne pravne stečevine, nadzora učinkovite provedbe ugrađenih zakonskih rješenja u praksi te pružanja podrške u jačanju institucionalnih kapaciteta.

Borba protiv korupcije na međunarodnoj razini započela je donošenjem Zakona o sprječavanju korupcije u inozemstvu (Foreign Corrupt Practices Act, 1977.). Taj

11 Ibidem.

12 Ibidem. 
je zakon zabranjivao američkim kompanijama da ponude, plate ili obećaju političaru za uslugu utjecaja, dobivanjem ili zadržavanjem nekog posla na sve kompanije koje imaju udjele ili glavnice registrirane u Sjedinjenim Američkim Državama ${ }^{13}$ i koje spadaju pod kontrolu komisije za nadzor financijskog poslovanja (SEC - Securitesand Exchange Commission). S tim u vezi, za američke kompanije pitanje opstanka na kompetitivnim tržištima bilo je pitanje borbe protiv korupcije u tim zemljama, zapravo, "spasonosna strategija" koja, osim toga, ima i podršku vlade, lokalnog i svjetskoga javnog mnijenja. ${ }^{14}$

Unutar dugotrajnog procesa i šireg konteksta suzbijanja korupcije i kaznenih inkriminacija podmićivanja na međunarodnom planu, u normativnom djelovanju Ujedinjenih naroda, Europske unije ${ }^{15}$ i Vijeća Europe ${ }^{16}$, doneseni su neki važni dokumenti koji su se neposredno ili posredno bavili i pitanjem (proširenog) oduzimanja imovinske koristi. Tu su ponajprije: Konvencija Ujedinjenih naroda protiv korupcije(UNCAC) i Konvencija UN-a protiv transnacionalnog organiziranog kriminaliteta (Palermo konvencija), koje se na načelnoj razini i u širem kontekstu bave pitanjem oduzimanja imovinske koristi, te Direktiva 2014/42/EU od 3. travnja 2014. godine, koja to pitanje uređuje zasebno i "specijalno".

\subsection{Konvencija $U N$-a protiv korupcije ${ }^{17}$}

Svrha donošenja UNCAC-a bila je promicanje i jačanje mjera za učinkovitije sprječavanje i borbu protiv korupcije; promicanje, olakšavanje i podupiranje međunarodne suradnje i tehničke pomoći u sprječavanju i borbi protiv korupcije, uključujući i u pogledu povrata imovine; te promicanje čestitosti, odgovornosti i pravilnog upravljanja javnim poslovima i državnom imovinom. UNCAC se primjenjuje u skladu s uvjetima predviđenim u njoj, na sprječavanje, istragu te progon korupcije, kao i na "zamrzavanje" sredstava, zapljenu, konfiskaciju te povrat imovinske koristi ${ }^{18}$ ostvarene kaznenim djelima određenim u skladu s tom Konvencijom (članak 3. stavak

13 Na temelju ovog zakona mnoge američke kompanije poput General Electric, Goodyear i IBM su kazneno procesuirane od 1998. do 2003., tako Obidario, S., Transnational Corruptionand Corporations: Regulating Briberythrough Corporate Liability, Englan i USA: Ashgate Publishing Limited, 2013., str. 76.

14 Vidjeti šire Kregar, J., Financijska praksa, 1997., 21 (5-6), str. 893-898.

15 U daljnjem tekstu: EU.

16 U daljnjem tekstu: VE.

17 Usvojena je na 58. sjednici Opće skupštine održanoj 31. listopada 2003., a stupila na snagu devedesetog dana od datuma polaganja tridesete isprave o ratifikaciji, prihvatu, odobrenju ili pristupu, odnosno 2005.

18 U čl. 2., pri definiranju temeljnih pojmova u svrhu svoje primjene, UNCAC daje i definiciju pojmova: imovina, imovinska korist, zamrzavanje ili zapljena, konfiskacija. Tako, "imovinu" označava kao imovinu bilo koje vrste, fizičku ili nefizičku, pokretnu ili nepokretnu, materijalnu ili nematerijalnu te pravne isprave ili instrumente koji dokazuju pravni naslov ili interes na takvoj imovini (čl. 2. toč. d) a "imovinsku korist ostvarenu kaznenim djelom" označava kao svaku imovinu koja je, izravno ili neizravno, proizašla iz počinjenja kaznenog djela ili je pribavljena njegovim počinjenjem (čl. 2. toč. e). 


\section{UNCAC-a). ${ }^{19}$}

Unutar poglavlja III. "Inkriminacije i djelatnost organa unutarnjih poslova", u članku 31., UNCAC posebno regulira pitanje zamrzavanja sredstava, zapljenu i konfiskaciju imovinske koristi. Navedenom konvencijskom odredbom regulirano je da je svaka država dužna poduzeti, u okviru svojega domaćeg pravnog poretka, potrebne mjere kako bi bila moguća konfiskacija: a) imovinske koristi ostvarene kaznenim djelom određenim u skladu s ovom Konvencijom ili imovine čija vrijednost odgovara toj imovinskoj koristi te b) imovine, opreme predmeta ili drugih sredstava uporabljenih ili namijenjenih za uporabu u počinjenju kaznenih djela određenih u skladu s ovom Konvencijom. ${ }^{20}$

Povrat imovine, UNCAC-ov segment kaznenopravne reakcije određuje kao jedno od temeljnih načela. S tim u vezi, predviđa mjere izravnog povrata imovie preko građanskih parnica, te mehanizme povrata unutar međunarodne suradnje u vezi s konfiskacijom. Također, ona u ovom dijelu potiče na međunarodnu suradnju radi konfiskacije i sklapanje dvostranih i višestranih ugovora i sporazuma radi povećanja učinkovitosti međunarodne suradnje te predviđa osnivanje Financijske obavještajne jedinice, koja bi imala zadaću primati, analizirati i pružati informacije o sumnjivim transakcijama nadležnim tijelima. ${ }^{21}$ Razumljivo je da UNCAC naglasak u ovom kontekstu stavlja na "povrat imovine" kao jednom od temeljnih načela borbe protiv korupcije, jer time države (posebno u razvoju i tranziciji u koje spada i Hrvatska) opterećene korupcijom dolaze do značajnih imovinskih sredstava koji su prijeko potrebni za rekonstrukciju i oporavak njihova gospodarskog sustava.

19 UNCAC obuhvaća osam poglavlja: 1. opće odredbe (članak 1. do 4.), 2. preventivne mjere (članak 5. do 14.), 3. inkriminacija i djelatnost organa unutarnjih poslova (članak 15. do 42.), 4. međunarodna suradnja (članak 43. do 50.), 5. povrat imovine (članak 51. do 59.), 6. tehnička pomoć i razmjena informacija (članak 60. do 62.), 7. mehanizmi provedbe (članak 63. do 64.) i 8. završne odredbe (članak 65. do 71.).

20 Naime, prema čl. 31. st. 1. UNCAC-a svaka država dužna je poduzeti, do najvećega mogućeg stupnja u okviru svoga domaćeg pravnog poretka, mjere potrebne kako bi bila moguća konfiskacija: a) imovinske koristi ostvarene kaznenim djelom određenim u skladu s ovom Konvencijom ili imovina čija vrijednost odgovara toj imovinskoj koristi, b) imovine, opreme ili drugih sredstava uporabljenih ili namijenjenih za uporabu u počinjenju kaznenih djela određenih u skladu s ovom Konvencijom.

21 Vidjeti članak 51. do 59. UNCAC-a. 


\subsection{Palermo konvencija ${ }^{22}$}

Palermo konvencija donesena je radi promicanja suradnje radi učinkovitijeg sprječavanja i suzbijanja transnacionalnog kriminaliteta. ${ }^{23,}{ }^{24} \mathrm{U}$ definiranju temeljnih pojmova, u članku 2., posebnu pažnju pridaje pojmovima: "imovina", "korist od kaznenog djela", "zamrzavanje" ili "privremeno oduzimanje" i "oduzimanje". Tako, pod imovinom podrazumijeva svaku vrstu imovine, bez obzira je li materijalna ili nematerijalna, pokretna ili nepokretna, ili se radi o ispravama koje dokazuju vlasništvo ili neko pravo nad takvom imovinom. Pojam "korist od kaznenog djela" znači svaku imovinu koja proizlazi ili je pribavljena, izravno ili neizravno, počinjenjem kaznenog djela. Pod pojmom "zamrzavanje" ili "privremeno oduzimanje" valja shvatiti privremenu zabranu prijenosa, promjene raspolaganja ili "premještanja" imovine ili privremeno preuzimanje u posjed i čuvanja imovine ili kontrole nad imovinom na temelju naloga koji je izdao sud ili drugo nadležno tijelo, dok "oduzimanje", gdje je to primjenjivo, uključuje pljenidbu, znači trajno oduzimanje imovine na temelju naloga suda ili drugog nadležnog tijela.

U okviru "šire rasprave" o suzbijanju transnacionalnog organiziranog kriminaliteta i koruptivnih pojava u koje, kao tipično, spada i podmićivanje, Palermo konvencija, u člancima od 12. do 14., važnost pridaje oduzimanju imovinske koristi regulirajući "odvojeno": 1) oduzimanje i privremeno oduzimanje (članak 12.), 2) međunarodnu suradnju u svrhu oduzimanja (članak 13.) ${ }^{25}$ i 3) raspolaganje oduzetom koristi od kaznenog djela ili oduzetom imovinom (članak 14.).

U dijelu regulacije oduzimanja i privremenog oduzimanja, Palermo konvencija obvezuje države stranke donijeti, maksimalno u okviru svojih domaćih pravnih sustava, mjere koje su nužne kako bi omogućile oduzimanje: a) koristi od kaznenih

22 Ovu konvenciju donijela je Opća skupština UN-a usvajanjem Rezolucije broj 55/255 na sjednici od 31. svibnja 2001. godine u Palermu. Stupila je na snagu 2003., a Republika Hrvatska ju je potpisala u prosincu 2003., a ratificirala 2002. Zakonom o potvrđivanju Konvencije Ujedinjenih naroda protiv transnacionalnoga organiziranog kriminaliteta, Protokola za sprječavanje, suzbijanje i kažnjavanje krijumčarenja ljudi, posebice žena i djece te Protokola protiv krijumčarenja migranata kopnom, morem i zrakom, kojim se dopunjuje Konvencija Ujedinjenih naroda protiv transnacionalnoga organiziranog kriminaliteta (NN-MU, br. 14/02 - objavljeno 22. studenoga 2002.). Konvencija je dopunjena s tri protokola kojima se želi spriječiti, suzbiti i kazniti trgovanje ljudima, posebno ženama i djecom; zatim krijumčarenje migrantima kopnom, morem i zrakom te nezakonitu proizvodnju oružja ili njihovih dijelova, što je i primarni predmet interesa njezina normativnog djelovanja.

23 Članak 1. Konvencije.

24 Prema čl. 3. Palermo konvencija primjenjuje se, osim ako je u njoj drukčije utvrđeno, na sprječavanje, istragu i progon: a) kaznenih djela utvrđenih na temelju članka 5., 6., 8. i 23. ove Konvencije i b) teškog kaznenog djela iz članka 2. ove Konvencije; kada je kazneno djelo transnacionalne prirode i uključuje zločinačku grupu. Kazneno djelo se smatra transnacionalnim: ako je počinjeno u više od jedne države; ako je počinjeno u jednoj državi, ali se značajan dio njegove pripreme, planiranja, uputa ili kontrole odvijao u drugoj državi; ako je počinjeno u jednoj državi, ali uključuje organiziranu zločinačku grupu koja se bavi zločinačkim djelovanjem u više od jedne države; ili ako je počinjeno u jednoj državi, ali ima značajne posljedice u drugoj državi.

25 Podrobno vidjeti čl. 13. Palermo konvencije. 
djela utvrđeni ovom Konvencijom ili imovine čija vrijednost odgovara toj koristi te b) imovine, predmeta ili drugih sredstava koja su korištena ili su se namjeravala koristiti u počinjenju kaznenih djela utvrđenim ovom Konvencijom. ${ }^{26}$ Također, države stranke su dužne donijeti mjere koje su nužne da bi se omogućila identifikacija, praćenje, "zamrzavanje" ili privremeno oduzimanje bilo kojeg predmeta iz stavka 1. ovog članka u svrhu mogućeg oduzimanja (članak 12. stavak 2.). Pritom, ako je korist od kaznenog djela djelomično ili u cijelosti ušla na drugi način u sastav imovine (počinitelja), ta imovina podliježe mjerama iz ovog članka umjesto primarnog oblika ostvarene koristi (članak 12. stavak 3.), a ako je korist od kaznenog djela "izmiješana" s imovinom stečenom na zakonit način, ta će imovina, bez utjecaja na ovlast glede zamrzavanja ili privremenog oduzimanja, biti predmetom oduzimanja do procijenjene vrijednosti "izmiješane" koristi (članak 12. stavak 4.). Dohodak ili druge prednosti dobivene od koristi od kaznenog djela, ili imovine u koju je transformirana ili konvertirana korist od kaznenog djela, ili od imovine s kojom je izmiješana korist koja je rezultat kaznenog djela, također će biti predmetom mjera iz ovog članka, isto $i \mathrm{u}$ istom omjeru kao i korist od kaznenog djela (članak 12. stavak 5.). ${ }^{27}$

U okviru reguliranja raspolaganja oduzetom imovinskom koristi od kaznenog djela ili oduzetom imovinom, konvencija, u članku 14. stavku 1., "ovlašćuje" države stranke raspolagati koristi od kaznenog djela ili imovinom koju je država stranka oduzela na temelju članka 12. ili članka 13. stavak 1 . Konvencije u skladu sa svojim domaćim pravom i upravnim postupcima. Dakle, u vezi s ovim pitanjem, Konvencija ostavlja određenu "slobodu" državama strankama. ${ }^{28}$

\subsection{Direktiva 2014/42/EU o zamrzavanju i oduzimanju predmeta $i$ imovinske koristi ostvarene kaznenim djelima u Europskoj uniji od 3. travnja 2014. ${ }^{29}$}

Zakonodavni okvir Unije, važeći prije 3. travnja 2014. godine i donošenja Direktive 2014/42/EU, sastojao se od: 1) Zajedničke akcije 98/699/PUP od 3. prosinca 1998. godine o pranju novca, utvrđivanju, praćenju, zamrzavanju, pljenidbi i oduzimanju imovine ili imovinske koristi ostvarenih kaznenim djelom, koju je Vijeće usvojilo na temelju članka K.3 UEU ${ }^{30}$; 2) Okvirne odluke VE-a 2001/500/PUP o pranju novca, identifikaciji, praćenju, zamrzavanju, pljenidbi i oduzimanju imovine i imovinske koristi ostvarene kaznenim djelima od 26. lipnja 2001. godine ${ }^{31}$, zatim

26 Vidjeti pobliže čl. 12. Palermo konvencije.

27 Shodno čl. 12. st. 6. u svrhe ovog članka i članka 13. (međunarodna suradnja u svrhu oduzimanja) svaka država stranka ovlastit će svoje sudove ili druga nadležna tijela da nalože dostupnost ili pljenidbu bankovne, financijske ili komercijalne evidencije. Države stranke neće odustati od postupanja u skladu s odredbama ovog stavka zbog povjerljivosti podataka banke.

28 Vidjeti i pobliže članak 14. stavak 2. i 3. Palermo konvencije.

29 Direktiva 2014/42/EU o zamrzavanju i oduzimanju predmeta i imovinske koristi ostvarene kaznenim djelima u Europskoj uniji (SL L 127 od 29. travnja 2014., u daljnjem tekstu: Direktiva 2014/42/EU), dostupna na: eur-lex.europa.eu i dana.europa.eu/eli/dir2014/42/oj/hrv/pdfa1a.

30 SL L 333 od 9. prosinca 1998.

31 SL L 182 od 5. srpnja 2001. 
3) Okvirne odluke VE-a 2003/577/PUP o izvršenju naloga za zamrzavanje imovine ili dokaza u Europskoj uniji od 22. srpnja 2003. godine ${ }^{32}$, 4) Okvirne odluke Vijeća 2005/212/PUP o oduzimanju imovinske koristi, sredstava i imovine pribavljene kaznenim djelima ${ }^{33}$ te 5) Okvirne odluka VE-a 2006/783/PUP o primjeni načela međusobnog priznavanja naloga za oduzimanje. ${ }^{34}$

Prema Izvješću Komisije za provedbu navedenih okvirnih odluka, navedeni postojeći režim oduzimanja i uzajamnog priznavanja naloga za zamrzavanje i oduzimanje imovine i imovinske koristi ostvarene kaznenim djelom, zbog razlika u pravu država članica, pokazao se tromim i neučinkovitim. ${ }^{35}$

Glavni motiv prekograničnog organiziranog kriminala, uključujući kriminalne organizacije "mafijaškog tipa," jest financijska dobit, zbog čega bi nadležna tijela trebala raspolagati sredstvima za praćenje, zamrzavanje i oduzimanje imovinske koristi ostvarene kaznenim djelima te upravljanje njome. Učinkovito sprječavanje i borbu protiv korupcije i organiziranog kriminala valjalo bi postići neutraliziranjem imovinske koristi ostvarene kaznenim djelima. Najučinkovitije sredstvo borbe protiv organiziranog kriminala i korupcije osiguranje je oštrih pravnih posljedica za počinjenje takvog kaznenog djela, kao i učinkovito otkrivanje te zamrzavanje i oduzimanje predmeta ili imovinske koristi ostvarene kaznenim djelom.

Stoga se ukazala potreba za donošenjem Direktive 2014/42/EU koja bi omogućila učinkovitije zamrzavanje te oduzimanje predmeta i imovinske koristi ostvarene kaznenim djelima.

\subsubsection{Predmet regulacije i temeljni pojmovi}

Predmet Direktive 2014/42/EU sastoji se u utvrđenju minimalnih pravila o zamrzavanju imovine s ciljem mogućega naknadnog oduzimanja te oduzimanja imovine u kaznenim stvarima, a kojim će se uskladiti postojeći režimi država članica za "zamrzavanje" i oduzimanje imovine i imovinske koristi ostvarene kaznenim djelima te time omogućiti uzajamno povjerenje i učinkovita prekogranična suradnja (članak 1. stavak 1.). Pritom, ona ne dovodi u pitanje postupke koje države članice mogu upotrebljavati za oduzimanje dotične imovine (članak 1. stavak 2.).

Direktiva, za svoje potrebe, u članku 2., definira nekoliko temeljnih pojmova: "imovinska korist", "imovina", "predmeti”, "oduzimanje", "zamrzavanje" i "kazneno djelo". Tako, imovinska korist znači svaku ekonomsku korist od kaznenih djela, neizravnu ili izravnu. Ona se može sastojati od bilo kojeg oblika imovine i uključuje svako naknadno reinvestiranje ili preoblikovanje izravne imovine koristi i svaku novčanu pogodnost. Imovina znači imovinu bilo koje vrste, neovisno o tomu je li materijalna ili nematerijalna, pokretna ili nepokretna, odnosno pravni dokument ili instrument kojim se dokazuje pravo na ili interes za takvu imovinu. Predmet podrazumijeva bilo koju imovinu koja se koristila ili se namjeravala koristiti, na bilo koji način, u cijelosti ili djelomično, kako bi se počinilo kazneno djelo ili kaznena

32 SL L 196 od 2. kolovoza 2003.

33 SL L 68 od 15. ožujka 2005.

34 SL L 328 od 24. studenoga 2006.

35 Vidjeti uvodni dio pod (10) Direktive 2014/42/EU. 
djela. Pod oduzimanjem razumijeva konačno oduzimanje imovine koju je odredio sud $\mathrm{u}$ vezi s kaznenim djelom, a pod zamrzavanjem podrazumjeva privremenu zabranu prijenosa, uništenja, konverzije, raspolaganja ili premještanje imovine odnosno privremeno čuvanje i nadzor imovine. Pod kaznenim djelom razumijeva djelo obuhvaćeno bilo kojim od instrumenata u članku 3. Direktive 2014/42/EU.

Dakle, valja primijetiti da regulative Direktive 2014/42/EU, u odnosu na dotada postojeći pravni režim, daje širu definiciju imovine koja može biti predmet "zamrzavanja" ili oduzimanja, ali i znatno šire definira koncept imovinske koristi. Naime, imovinska korist, prema izloženom, obuhvaća kako izravnu imovinsku korist stečenu kaznenim djelima i sve neizravne koristi, uključujući i naknadno reinvestirane ili preoblikovane izravne imovinske koristi. S tim u vezi, postupak zamrzavanja ili oduzimanja može obuhvaćati bilo koju imovinu, pa i onu koja je bila podložna preoblikovanju u drugu imovinu te onu koja je pomiješana s imovinom stečenom iz zakonitih izvora, ali do procijenjene vrijednosti pomiješane imovinske koristi.

\subsubsection{Područje primjene}

Direktiva se primjenjuje samo na kaznena djela koja su dio područja primjene $u$ članku 3. navedenih instrumenata. U tom smislu, važno je istaknuti da se ona, među ostalim, primjenjuje i slučaju kada je imovina ili imovinska korist ostvarena kaznenim inkriminacijama podmićivanja, neovisno o tomu radi li se o javnom ili privatnom sektoru. Ovo stoga što se Direktiva primjenjuje na Konvenciju EU-a o borbi protiv korupcije $^{36}$, ali također i na Okvirnu odluku VE-a 2003/568/PUP od 22. srpnja 2003. godine. $^{37}$

\subsubsection{Posebno o (proširenom) oduzimanju imovinske koristi}

U pogledu koncepta oduzimanja imovinske koristi, Direktiva, u članku 4. stavku 1., nameće obvezu državama članicama da poduzmu potrebne mjere kako bi se onemogućila oduzimanje, u cijelosti ili djelomično, predmeta i imovinske koristi ili imovine čija vrijednost odgovara takvim predmetima ili imovinskoj koristi, podložno pravomoćnoj presudi za kazneno djelo, koja također može proizlaziti iz postupka u odsutnosti.

U odnosu na postojeću regulativu Unije, Direktiva uvodi i mogućnost proširenog oduzimanja $^{38}$, ali i oduzimanja od trećih osoba na koje je imovina ili imovinska korist ostvarena kaznenim djelima prenesena od strane osumnjičenika odnosno optuženika ${ }^{39}$.

Prošireno oduzimanje trebalo bi biti moguće ako je sud u određenom predmetu koji se vodi radi počinjenja kaznenog djela koje može izravno ili neizravno dovesti do gospodarske koristi, s obzirom na posebnosti konkretnog slučaja, utvrdio da je vrijednost osuđenikove imovine nerazmjerna njegovim zakonitim primanjima, pa se u tom slučaju smatra da ta imovina potječe iz kriminalne aktivnosti. Naime, prema

36 Vidjeti članak. 3. stavak 1. točka (a) Direktive.

37 Vidjeti članak 3. stavak 1. točka (f) Direktive.

38 Vidjeti članak 5. Direktive 2014/42/EU.

39 Vidjeti članak 6. Direktive 2014/42/EU. 
članku 5. stavka 1. Direktive 2014/42/EU, države članice donose potrebne mjere kako bi omogućile oduzimanje, u cijelosti ili djelomično, imovine u posjedu osobe osuđene za kazneno djelo koje može neizravno ili izravno dovesti do gospodarske koristi, ako sud, na temelju okolnosti slučaja, uključujući posebne činjenice i dostupne dokaze, npr. da je vrijednost onoga što osuđenik ima u vlasništvu u nerazmjeru sa zakonitim prihodom osuđenika, smatra se da dotična imovina potječe od kaznenih radnji. S tim $\mathrm{u}$ vezi, a za potrebe primjene proširenog oduzimanja (imovinske koristi), Direktiva u članku 5. stavku 2., dodatno, određuje: 1) pojam kaznenog djela uključuje najmanje aktivnu i pasivnu korupciju u privatnom sektoru, kako je navedeno u članku 2. Okvirne odluke 2003/568/PUP, kao i aktivnu i pasivnu korupciju u kojoj sudjeluju dužnosnici institucija Unije ili država članica, kako je navedeno u člancima 2. i 3. Konvencije o borbi protiv korupcije u kojoj sudjeluju dužnosnici (točka a); 2) djela u vezi sa sudjelovanjem u zločinačkoj organizaciji, kako je navedeno u članku 2. Okvirne odluke 2008/841/PUP, barem u slučajevima u kojima je djelo dovelo do gospodarske koristi (točka b); 3) poticanje sudjelovanja djeteta u pornografskim predstavama ili zapošljavanje djeteta $u$ te svrhe, ostvarivanje dobiti iz istoga ili iskorištavanje djeteta na drugi način u te svrhe ako je dijete dosegnulo dob za pristanak na spolni odnos, kako je navedeno u članku 4. stavku 2. Direktive 2011/93/EU; distribucija, širenje ili posredovanje dječje pornografije, kako je navedeno u članku 5. stavku 4. te Direktive; nuđenje, dobavljanje ili stavljanje na raspolaganje dječje pornografije, kako je navedeno u članku 5. stavku 5. te Direktive; proizvodnja dječje pornografije, kako je navedeno u članku 5. stavku 6. te Direktive (točka c); te 4) nezakonito ometanje sustava i nezakonito ometanje podataka, kako je navedeno u člancima 4. i 5. Direktive 2013/40/EU, kada je značajan broj informacijskih sustava pogođen korištenjem nekog od alata iz članka 7. iste Direktive, namijenjenog ili prilagođenog za tu svrhu; namjerna proizvodnja, prodaja, nabava radi korištenja, uvoz, distribucija ili drugo stavljanje na raspolaganje alata koji se koriste u svrhu počinjenja kaznenih djela, barem kada nije riječ o lakšim slučajevima, iz članka 7. te Direktive (točka d).

S obzirom na to da je sve učestalija praksa osumnjičenika ili optuženika da prenesu imovinu "poznatoj" trećoj osobi, a kako regulativa Unije prije 3. travnja 2014. godine nije poznavala obvezujuća pravila o oduzimanju imovine trećim osobama, Direktiva 2014/42EU uvodi bitnu novinu u smislu mogućnosti oduzimanja imovine i imovinske koristi ostvarene kaznenim djelom od trećih osoba na koje je osumnjičenik odnosno optuženik prenio nezakonito ostvarenu imovinu ili imovinsku korist. Isto tako, Direktiva omogućuje oduzimanje od trećih osoba samo pod uvjetom da su te treće osobe znale ili morale znati da je namjera prijenosa ili stjecanja bila izbjegavanje oduzimanja, što utvrđuje sud u svakom predmetu posebno, uzimajući u obzir sve relevantne činjenice i okolnosti konkretnog slučaja, a posebno činjenicu da su mogući prijenos ili stjecanje obavljeni besplatno ili u zamjenu za iznos znatno niži od tržišne vrijednosti. ${ }^{40}$

40 Prema čl. 6. st. 1. Direktive države članice poduzimaju potrebne mjere kako bi omogućile oduzimanje imovinske koristi ili drugu imovinu čija vrijednost odgovara imovinskoj koristi koju je osumnjičenik odnosno optuženik neizravno ili izravno prenio trećim stranama, ili su je treće strane stekle od osumnjičenika odnosno optuženika, barem ako su te treće strane znale ili su morale znati da je namjera prijenosa ili stjecanja bila izbjegavanje oduzimanja na temelju 
S druge strane, radi zaštite osoba koje su pogođene mjerama oduzimanja imovine i imovinske koristi ostvarene kaznenim djelom, Direktiva jamči nekoliko važnih zaštitnih mjera: a) nalog za oduzimanje mora se priopćiti "pogođenoj" osobii", b) nalog za oduzimanje mora sadržavati razloge izdavanja ${ }^{42}$, c) "pogođenoj osobi” mora se omogućiti učinkovita sudska zaštita povodom naloga za oduzimanje ${ }^{43}$, d) osoba čija je imovina zahvaćena nalogom za oduzimanje ima pravo na odvjetnika tijekom čitavog postupka oduzimanja u vezi s određivanjem imovine koristi i predmeta kako bi ostvarila svoja prava, te o tom pravu moraju obavijestiti nadležna tijela ${ }^{44}$, e) treće osobe imaju pravo tražiti (stjecanje) prava vlasništva i drugih imovinskih prava u vezi s oduzetom imovinom ili imovinskom koristi ${ }^{45}$, te f) ako, kao rezultat kaznenog djela, žrtve imaju potraživanja prema osobama koje podliježu mjeri oduzimanja predviđenoj na temelju ove Direktive, države članice u obvezi su poduzeti potrebne mjere kako bi se osiguralo da mjera oduzimanja ne sprječava te žrtve u traženju naknade za svoja potraživanja. ${ }^{46}$

Pored ovih posebnih zaštitnih mjera, države članice dužne se poduzeti sve potrebne mjere kako bi osigurale da osobe "pogođene" mjerama oduzimanja predviđenim u okviru ove Direktive imaju pravo na učinkovita pravna sredstva i na pravično suđenje te imaju pravo sačuvati svoja prava, na temelju odredbe članka 8 . stavka 1. Direktive 2014/42/EU.

Konačno, Direktiva, u članku 10., obvezuje države članice osigurati adekvatno upravljanje oduzetom imovinom s ciljem mogućega naknadnog oduzimanja, uz predviđanje prodaje ili prijenosa zamrznute imovine u slučaju potrebe, kao i korištenja oduzete imovine za opće dobro (javni interes) ili u socijalne svrhe.

\subsubsection{O zamrzavanju imovine i imovinske koristi $i$ zaštitnim mjerama}

"Zamrzavanje" i oduzimanje imovine i imovinske koristi ostvarene kaznenim djelom u okviru promatrane Direktive postavljeni su kao autonomni koncepti koji ne bi trebali sprječavati države članice u provođenju Direktive pomoću instrumenata koji bi u skladu s nacionalnim pravom bili smatrani sankcijama ili drugim vrstama mjera.

Tako je člankom 7. stavkom 1. Direktive 2014/42/EU predviđena obveza državama članicama da poduzimaju potrebne mjere kako bi omogućile zamrzavanje imovine radi mogućeg naknadnog oduzimanja, što uključuje i hitne aktivnosti koje se trebaju poduzeti u slučaju potrebe kako bi se sačuvala imovina. Pored toga, Direktiva, u članku 9., obvezuje države članice u poduzimanju potrebnih mjera da bi se omogućilo učinkovito otkrivanje i praćenje imovine koju treba zamrznuti i oduzeti.

S druge strane, radi zaštite osoba koje su pogođene mjerama zamrzavanja

konkretnih činjenica i okolnosti, uključujući činjenicu da su prijenos ili stjecanje provedeni besplatno ili u zamjenu za iznos znatno niži od tržišne vrijednosti, s time da stavak 1 . ne dovodi u pitanje prava bona fide (u dobroj vjeri) trećih strana (članak 6. stavak 2. Direktive).

41 Vidjeti čl. 8. st. 6. Direktive 2014/42/EU.

42 Vidjeti čl. 8. st. 6. Direktive 2014/42/EU.

43 Vidjeti čl. 8. st. 6. Direktive 2014/42/EU.

44 Vidjeti čl. 8. st. 7. Direktive 2014/42/EU.

45 Vidjeti čl. 8. st. 9. Direktive 2014/42/EU.

46 Vidjeti čl. 8. st. 10. Direktive 2014/42/EU. 
imovine i imovinske koristi ostvarene kaznenim djelom, Direktiva jamči nekoliko važnih zaštitnih mjera: a) nalog za zamrzavanje mora se priopćiti "pogođenoj osobi" što je prije moguće nakon njezina izvršenja ${ }^{47}$, b) nalog za zamrzavanje mora sadržavati razloge izdavanja ${ }^{48}$, c) nalog je privremene prirode, a ostaje na snazi samo onoliko dugo koliko je to potrebno da se sačuva imovina s ciljem mogućeg naknadnog oduzimanja $^{49}$, d) odnosno osumnjičeniku optuženiku mora se omogućiti učinkovita sudska zaštita od naloga za zamrzavanje $\mathrm{e}^{50}$, te e) zamrznuta imovina koja nije naknadno oduzeta mora se odmah vratiti onoj osobi kojoj je zamrznuta. ${ }^{51}$

Pored iznesenih posebnih zaštitnih mjera, države članice dužne se poduzeti sve potrebne mjere kako bi osigurale da osobe pogođene mjerama zamrzavanja (ali, kako je ranije izneseno, i mjerama oduzimanja) predviđenim u okviru ove Direktive imaju pravo na učinkovita pravna sredstva i na pravično suđenje kako bi sačuvale svoja prava, na temelju odredbe članka 8 . stavka 1. Direktive 2014/42/EU.52

\subsection{O usklađenosti KZ-a s izloženom pozitivnom međunarodnom regulativom koja uređuje (prošireno) oduzimanje imovinske koristi}

\subsubsection{Prikaz pozitivne regulacije $K Z-a$}

Koliku važnost Kazneni zakon iz 2011. ${ }^{53}$ pridaje oduzimanju imovinske koristi, svjedoči i činjenica da je ovaj institut, za razliku od dotadašnje regulacije starog

47 Vidjeti čl. 8. st. 2. Direktive 2014/42/EU.

48 Vidjeti čl. 8. st. 3. Direktive 2014/42/EU.

49 Vidjeti čl. 8. st. 3. Direktive 2014/42/EU.

50 Vidjeti čl. 8. st. 4. Direktive 2014/42/EU.

51 Vidjeti čl. 8. st. 5. Direktive 2014/42/EU.

52 Direktiva obvezuje osigurati i adekvatno upravljanje zamrznutom imovinom s ciljem mogućeg naknadno oduzimanja, uz predviđanje mogućnosti prodaje ili prijenosa zamrznute imovine $\mathrm{u}$ slučaju potrebe.

53 Kazneni zakon (NN, br. 125/11., 144/12., 56/1.5 i 61/15., u daljnjem tekstu: KZ). 
Kaznenog zakona ${ }^{54}$, "ugrađen" ${ }^{55} \mathrm{u}$ temeljna načela kaznenog materijalnog prava. ${ }^{56,57,}$ ${ }^{58,59}$ Definiranje i svrstavanje ovog načela u temeljne odredbe KZ-a predstavlja važnu novinu u odnosu na dotadašnju zakonsku regulaciju. ${ }^{60}$ Zakonodavac je time očito jasno i nedvosmisleno htio izraziti stajalište o tom pitanju ${ }^{61}$ Ovo temeljno načelo

54 Kazneni zakon (NN, br. 110/97., 27/98. - ispravak, 50/00., 129/00., 51/01., 111/03., 190/03., 105/04., 84/05. - ispravak, 71/06., 110/07., 152/08. i 57/11., u daljnjem tekstu: KZ/97).

$55 \mathrm{KZ} / 97$, u općem dijelu, u prvoj glavi "Temeljne odredbe”, nije poznavao kao zasebno načelo, načelo oduzimanja imovinske koristi.

$56 \mathrm{U}$ postupovnom smislu oduzimanje imovinske koristi u hrvatskom pravnom sustavu regulirano je posebnim Zakonom o postupku oduzimanja imovinske koristi ostvarene kaznenim djelom i prekršajem (NN, br. 145/10., u daljnjem tekstu: ZOPOIK). Naime, ovim zakonom specijalno se uređuje: a) postupak utvrđivanja imovinske koriste ostvarene kaznenim djelom, b) postupak osiguranja oduzimanja imovinske koristi ostvarene kaznenim djelom, c) postupak ovrhe odluke o oduzimanju imovinske koristi ostvarene kaznenim djelom, d) postupanje s oduzetom imovinom i imovinom glede koje je određena privremena mjera, e) oduzimanja ostvarenje prava osobe oštećene kaznenim djelom te f) zaštita prava treće osobe. O postupovnim aspektima oduzimanja imovinske koristi vidjeti Ivičević Karas, E., Zakon o postupku oduzimanja imovinske koristi ostvarene kaznenim djelom i prekršajem: neka otvorena pitanja i moguća rješenja, Hrvatski ljetopis za kazneno pravo i praksu, 2011., str. 557-578. No, ne treba zanemariti da je oduzimanje imovinske koristi, na općenitoj razini, regulirano i odredbama Zakona o kaznenom postupku (NN, br. 152/0.8, 76/09., 80/11., 91/12., 143/12., 56/13., 145/13. i 152/14., u daljnjem tekstu: ZKP).

57 Ivičević smatra da je načelo oduzimanja imovinske koristi posljedica višeg načela pravednosti prema kojem nitko ne može zadržati bilo kakvu, pa tako ni onu imovinsku korist od kaznenog djela - Ivičević, E., Oduzimanje imovinske koristi stečene kaznenim djelom, Hrvatsko udruženje za kaznene znanosti i praksu Ministarstva unutarnjih poslova Republike Hrvatske, Zagreb, 2004., str. 94. S tim u vezi, Horvatić je naveo da oduzimanje imovinske koristi nije niti sigurnosna mjera, a niti kaznenopravna sankcija, već je posljedica načela pravednosti, Horvatić, Ž., Novoselec, P., Kazneno pravo - opći dio, Zagreb, 2001., str. 463.

58 Oduzimanje imovinske koristi uvedeno je u naše kazneno zakonodavstvo novelom KZ-a iz 1959. Novela je stupila na snagu 1. siječnja 1960. Oduzimanje imovinske koristi imalo je karakter kaznene sankcije i status sigurnosne mjere do 1977., a uvedeno je radi sprječavanja bogaćenja koje se temelji na izvršenju kaznenog djela. Do tada se oduzimanje imovinske koristi provodilo posebnim propisima kod pojedinih kaznenih djela (npr. primanja i davanja mita) kao i izricanjem sigurnosne mjere oduzimanja predmeta koje je pored ostalog obuhvaćalo i oduzimanje predmeta koji su dobiveni kao nagrada za izvršenje kaznenih djela - tako Bačić, F., Kazneno pravo, Opći dio, Zagreb, 1998., str. 470-471.

59 Mjera oduzimanja imovinske koristi prvi put je regulirana u Općem kaznenom zakoniku Kraljevine Norveške 1902., dakle prije 105 godina, te se u početku nije smatrala kaznom, dok je poslije dobila status sporedne kazne. Njezina je primjena ovisila o tome je li prijestupom postignuta kakva dobit. Zakonik je predviđao da se dobit koja je pribavljena kakvim kažnjivim djelom, ili iznos novca koji odgovara vjerojatnoj dobiti, može presudom oduzeti od krivca ili, onoga u čijem je interesu krivac radio uz odredbu da mu se oduzima u korist državne blagajne, stoji i odredba da će se, kad oštećenik kaznenim djelom ne može dobiti naknadu od krivca, oduzeti predmeti upotrijebiti za njegovu - tako Staničić, T., Pravna priroda instituta oduzimanja imovinske koristi i njegovo mjesto u krivičnom pravu, Zbornik radova Pravnog fakulteta u Splitu, Split, 1979., str. 169-170.

60 Slično i Garačić, A., Kako prečeste izmjene kaznenih zakona utječu na pravnu sigurnost, Informator, br. 6401., Zagreb, 2016., str. 2.

61 Iz obrazloženja Konačnog prijedloga Kaznenog zakona KLASA: 740-02/11-01/03, URBROJ: 5030106-11-4 od 6. listopada 2011. (str. 127.) - dostupno na: www.sabor.hr/Default. 
kaznenog prava poznato je u većini pravnih sustava i imanentno je samom pojmu nedopustivosti stjecanja bilo kakve imovine stečene izvršavanjem kaznenog djela. ${ }^{62}$

Načelo oduzimanja imovinske koristi, kako je definirano u članku 5. KZ-a, podrazumijeva da nitko ne može zadržati imovinsku korist ostvarenu protupravnom radnjom. Tom je odredbom jasno izraženo gotovo beziznimno načelo "da se zločin ne isplati." ${ }^{63}$ Ovo se posebno tiče kaznenih djela gospodarskog kriminaliteta i organiziranog kriminala, ali i korupcijskih kaznenih djela, jer je glavni motiv počinitelja istih stjecanje "pozamašne" koristi. ${ }^{64}$ Stoga se, oduzimanje imovinske koristi pokazuje kao učinkovito pravno sredstvo u borbi protiv korupcijskih kaznenih inkriminacija, organiziranog kriminala i kaznenih djela gospodarskog kriminala. ${ }^{65,66}$

$\mathrm{U}$ posebnom dijelu $\mathrm{KZ}$ je oduzimanju imovinske koristi posvetio dva članka članak 77. koji regulira uvjete i način oduzimanja imovinske koristi kod kaznenih djela općenito i članak 78. koji uređuje prošireno oduzimanje imovinske koristi.

Pritom je KZ u članku 87. stavku 22. i 23. definirao je pojmove "imovinske koristi" $i$ "imovine" koji su imanentni pri razmatranju instituta oduzimanja imovinske koristi. Tako, pod "imovinskom korišću od kaznenog djela" podrazumijeva neposrednu imovinsku korist od kaznenog djela koja se sastoji od svakog uvećanja ili sprečavanja umanjenja imovine do kojeg je došlo počinjenjem kaznenog djela, imovinu u koju je promijenjena ili pretvorena neposredna imovinska korist od kaznenog djela kao i svaku drugu korist koja je dobivena od neposredne imovinske koristi od kaznenog djela ili imovine u koju je promijenjena ili pretvorena neposredna imovinska korist od kaznenog djela bez obzira nalazi li se na području Republike Hrvatske ili izvan nje (članak 87. stavak 22.). Pritom, pojam «imovine» definira kao imovinu bilo koje vrste, neovisno o tome je li materijalna ili nematerijalna, pokretna ili nepokretna, odnosno pravni dokumenti ili instrumenti kojima se dokazuje pravo na ili interes za takvu imovinu (članak 87. stavak 23.). "Navedenim definicijama hrvatski je zakonodavac ne samo precizirao pojam imovinske koristi i imovine, nego je i zakonom propisao da imovinska korist može biti pribavljena kako izravno počinjenjem kaznenog djela tako i neizravno, njezinim daljnjim korištenjem, čime su predmetne definicije usklađene s odgovarajućim međunarodnim konvencijama i propisima Europske unije." ${ }^{\prime 67,68}$ Uspoređujući iznesene definicije s onim sadržanim u članku 3. stavku 1. točki 1. i

aspx?art=41259.

62 Kos, D., Problematika oduzimanja imovinske koristi, Hrvatski ljetopis za kazneno pravo i praksu, Zagreb, 1998., str. 757.

63 Ibidem, bilj. 56. (Iz obrazloženja...), str. 127.

64 Slično Novosel, D., Financijske istrage i progon počinitelja gospodarskog kriminaliteta, Hrvatski ljetopis za kazneno pravo i praksu, Zagreb, 2007., str. 739.

65 Slično ibidem bilj. 64. (Novosel, 2007.).

66 Organizirani kriminal, gospodarski kriminal i korupcija predstavljaju jedan od najznačajnijih izvora ugrožavanja nacionalne sigurnosti u Republici Hrvatskoj tako Roksandić Vidlička, S.; Šamota, Galjer, M., Političko-gospodarski kriminalitet i prošireno oduzimanje imovinske koristi: Quo vadis, Hrvatska?, Hrvatski ljetopis za kazneno pravo i praksu, Zagreb, 2015., str. 531.

67 Ibidem bilj. 65. (Roksandić i dr., 2015.), str. 534.

68 Vidjeti pobliže 2.2. i 2.3. 
2. ZOPOIK-a ${ }^{69}$, zakonodavac je u KZ-u znatno šire definirao predmetne pojmove. ${ }^{70}$

$\mathrm{U}$ ovom dijelu, valja skrenuti pozornost $\mathrm{i}$ da se, legislativnom promjenom Zakona o odgovornosti pravnih osoba za kaznena djela ${ }^{71}$ iz 2012. godine ${ }^{72}$ odredbe KZ-a i posebnih zakona, primjenjuju i na oduzimanje imovinske koristi i oduzimanje predmeta i u slučaju odgovornosti pravnih osoba za kaznena djela. ${ }^{73}$

\subsubsection{O oduzimanju imovinske koristi općenito (po članku 77. KZ-a)}

Prema članku 77. stavku 1. KZ-a imovinska korist oduzet će se sudskom odlukom kojom je utvrđeno da je ostvarena protupravna radnja, ali i od osobe na koju je prenesena ako nije stečena u dobroj vjeri. Ovom odredbom KZ naglašava da je oduzimanje imovinske koristi obveza suda, pri čemu je dostatno da je ostvarena protupravna radnja. Dakle, imovinska korist će se oduzeti kako počinitelju i neubrojivu počinitelju, tako i osobi koja nije kriva jer je primjerice postupala u neotklonjivoj zabludi $^{74}$, ali i svakoj drugoj osobi koja je nije stekla u dobroj vjeri (osobi za koju je pribavljena ili na koju je prenesena bez naknade ili uz naknadu koja očigledno ne odgovara njezinoj stvarnoj vrijednosti odnosno od osobe koja je znala ili mogla znati da je imovina stečena kaznenim djelom. $)^{75}$

Prema određenju članka 77. stavka 2. i 3. KZ-a imovinskopravni zahtjev oštećenika ima pravo prvenstva u odnosu na oduzimanje imovinske koristi. Naime, ako je oštećeniku dosuđen imovinskopravni zahtjev koji po prirodi i sadržaju odgovara pribavljenoj imovinskoj koristi, oduzet će se dio imovinske koristi koji prelazi dosuđeni imovinskopravni zahtjev (stavak 2.). Dakle, u odnosu na imovinskopravni zahtjev, institut oduzimanja imovinske koristi je supsidijaran. ${ }^{76}$ Naime, ovaj institut nema svrhu omogućiti državi da dođe do neke materijalne koristi radi "bogaćenja" izvršenjem kaznenih djela, čime bi ona svojevrsno participirala u kriminalnoj dobiti,

69 Prema članku 3. stavku 1. ZOPOIK-a imovinska korist ostvarena kaznenim djelom, u skladu s ovim i drugim zakonom, jest svako povećanje ili sprječavanje smanjenja imovine koja potječe od kaznenog djela (točka 1.), a imovina predstavlja stvari i prava koja je stekao počinitelj kaznenog djela i prekršaja ili povezana osoba, a obuhvaća sve stvari i prava koja mogu biti predmet ovrhe te posebno nekretnine i pokretnine, tražbine, poslovne udjele, dionice, novac, plemenite metale i drago kamenje u vlasništvu, posjedu ili pod kontrolom počinitelja kaznenog djela ili povezane osobe.

70 Ovako šire postavljene definicije pojmova imovina i imovinska korist znatno su pogodnije za praksu, posebice kad se ima u vidu kako se u današnje doba globalizacije, digitalizacije i bitcoina promijenio ne samo način kako djeluju gotovo svi počinitelji kaznenih djela u smislu kreiranja novih načina počinjenja tih djela, nego i načini i oblici u kojima se ta protupravno ostvarena korist ostvaruje, te posljedično tomu povećava i skriva od tijela progona - tako ibidem bilj. 65. (Roksandić i dr., 2015.), str. 535.

71 Zakon o odgovornosti pravnih osoba za kaznena djela (NN, br. 151/03., 110/07., 45/11. i 143/12., u daljnjem tekstu: ZOPOIK).

72 Ova novela ZOPOIK-a je unesena Zakonom o izmjenama i dopunama Zakona o odgovornosti pravnih osoba za kaznena djela (NN, br. 143/12.).

73 Vidjeti brisani čl. 20. ZOPOIK-a.

74 Tako Pavlović, Š., Kazneni zakon, Libertin naklada, Rijeka, 2012., str. 156.

75 Ibidem bilj. 60 (Pavlović, 2012.).

76 Tako je bilo predviđeno i u čl. 82. st. 4. KZ/97-a. 
već naprotiv, osigurati da nezakonito ostvarena imovinska korist ne ostane "u rukama" "posjednika" koji na to nema pravo. ${ }^{77}$

Sud će oduzeti imovinsku korist i ako se oštećenika uputi da imovinskopravni zahtjev može ostvariti u parnici (članak 77. stavak 3. KZ-a). Prema ocjeni predlagatelja, ova odredba inkorporirana je u tekst KZ-a kako bi se osiguralo da je imovinska korist zaista oduzeta, odnosno kako bi se izbjegla mogućnost da ne bude oduzeta ako oštećenik ne pokrene parnični postupak na koji ga je uputio kazneni sud. ${ }^{78}$

Ako nije moguće oduzimanje stvari ili prava ostvarenih kao imovinska korist $u$ cijelosti ili djelomično, sud će naložiti počinitelju isplatu odgovarajuće protuvrijednosti u novčanom iznosu. Plaćanje se može odrediti obročno (članak 77. stavak 4. KZ-a).

Sagledavajući iznesene zakonske norme, možemo zaključiti - prvo, osnova za oduzimanje imovinske koristi je sudska odluka kojom je utvrđeno da je ostvarena protupravna radnja. ${ }^{79}$ Imovinska korist koja je ostvarena izvršenjem kaznenog djela za koje se sudi počinitelju oduzima se supsidijarno i razmjerno dijelu koji prelazi dosuđeni imovinskopravni zahtjev. Drukčije izneseno, oduzimanje imovinske koristi primjenjuje se u kaznenom postupku uz ispunjenje ovih triju pretpostavki: 1) da je odlukom kaznenog suda utvrđeno kako je ostvarena protupravna radnja, 2) da je u postupku utvrđeno kako je tim kaznenim djelom, ili, u vezi s njegovim počinjenjem, pribavljena imovinska korist te 3) da imovinska korist nije u cijelosti konzumirana dosuđenim imovinskopravnim zahtjevom oštećenika. ${ }^{80}$

Zakonske odredbe, kojima je uređen ovaj institut, kogentne (prisilne) su prirode, jer sud je dužan (dakle, mora) po službenoj dužnosti oduzeti imovinsku korist ${ }^{81}$, osim, iznimno, ako se radi o neznatnoj imovinskoj koristi. ${ }^{82} \mathrm{No}$, i u potonjem slučaju, prema zakonskom određenju, sud može, ostavlja mu se na slobodnu procjenu (volju), odlučiti hoće li se i takva (neznatna) imovinska korist oduzeti. ${ }^{83}$ U svakom slučaju, ova mjera

77 Slično je zaključio i Brkić analizirajući članak 82. stavak 1. i 2. KZ/97-a - Brkić, B., Oduzimanje predmeta i imovinske koristi u kaznenom postupku - dostupno na: www.vsrh.hr.

78 Ibidem bilj. 56. (Iz obrazloženja), str. 159. Tako i ibidem bilj. 60. (Pavlović, 2012.), str. 157.

$79 \mathrm{KZ} / 97$, kao osnovi za oduzimanje imovinske koristi, govori o odluci "kojom se utvrđuje da je kazneno djelo počinjeno" - usporedi članak 77. stavak 1. KZ-a sa stipulacijom odredbe članak 82. stavak 1. KZ/97-a. S tim u vezi, analizom čl. 82. st. 1. KZ/97-a Garačić je istaknula: "Imovinska korist je čisti višak imovine okrivljenika koju je pribavio kaznenim djelom i koju je zadržao do donošenja presude o počinjenju djela, a osnova za njezino oduzimanje je pravomoćna sudska odluka kojom je utvrđeno da je kazneno djelo počinjeno", tako Garačić, A., Kazneni zakon u sudskoj praksi, Zagreb, 2001., str. 122.

80 Slično Ivičević, E., Oduzimanje imovinske koristi stečene kaznenim djelom, Hrvatsko udruženje za kaznene znanosti i praksu Ministarstva unutarnjih poslova Republike Hrvatske, Zagreb, 2004., str. 99. Ova je razmatranja Ivičević iznijela pri strukturnom prikazu postupka oduzimanja imovinske koristi po regulaciji KZ/97-a.

81 Analizirajući uređenje predmetnog instituta po KZ/97 slično je zaključio i Kaleb, Z., Novo uređenje instituta oduzimanja imovinske koristi prema noveli Kaznenog zakona, Hrvatski ljetopis za kazneno pravo i praksu, Zagreb, 2003., str. 453.

82 Shodno čl. 77. st. 5. KZ-a.

83 Pritom, oduzeta imovinska korist neće se umanjiti za iznos sredstava uloženih u kriminalnu djelatnost, na temelju čl. 77. st. 6. KZ-a. Dakle, ovom odredbom izričito se regulira da se imovinska korist računa u "bruto", a ne u "neto" iznosu. S tim u vezi, imovinska korist implicira čistu dobit do koje se dolazi nakon što se odbiju nužni izdaci i troškovi, tako ibidem bilj. 64. 
s generalnog i posebnog preventivnog stajališta ima cilj nedvojbeno pokazati da se zločin ne isplati te odvratiti druge od činjenja novih kaznenih djela imovinskog karaktera. ${ }^{84}$

\subsubsection{Prošireno oduzimanje imovinske koristi (po članku 78. KZ-a)}

Promatrajući općenito, prema regulaciji članka 77. KZ-a, institut oduzimanja imovinske koristi može se primijeniti na sva kaznena djela. Ovo se odnosi i na sve kaznene inkriminacije podmićivanja predviđene u KZ-u. U slučaju počinjenja kaznenih djela iz nadležnosti Ureda za suzbijanje korupcije i organiziranog kriminaliteta ${ }^{85,86,}$ 87,88 , primijenit će se tzv. prošireno oduzimanje imovinske koristi koje je uređeno “specijalnim" odredbama članka 78. KZ-a. Naime, prema članku 78. stavku 1. KZa, na prošireno oduzimanje imovinske koristi od kaznenog djela za koje je nadležan USKOK i za kaznena djela iz Glave XVII. ${ }^{89}$ i Glave XXV. ${ }^{90}$ ovoga Zakona, ako je tim djelima ostvarena imovinska korist, primjenjuju se odredbe članka 77. ovoga Zakona ako tim člankom nije drukčije propisano. Dakle, ako se radi o pasivnom podmićivanju, pod uvjetom da je kaznenim djelom ostvarena imovinska korist, pravo prvenstva u primjeni imaju odredbe članka 78. KZ-a, a supsidijarno, odredbe članka 77. KZ-a. ${ }^{91}$ Možemo zaključiti da je pozitivnom regulacijom KZ-a primjena ovog

(Pavlović, 2012.), str. 157 i 158.

84 Slično Mrčela, M., Pravni i praktični aspekti oduzimanja imovinske koristi u kaznenom postupku, Policija i sigurnost, Zagreb, 1999., str. 287.

85 U daljnjem tekstu: USKOK.

86 Osnovan, kao posebno državno odvjetništvo, za područje cijele Republike Hrvatske. Pravni temelj za ustroj USKOK predstavlja Zakon o Uredu za suzbijanje korupcije i organiziranog kriminala iz 2001. (NN, br. 88/01. stupio na snagu 19. listopada 2001.).

87 Ustroj USKOK-a kao središnjeg tijela koje će biti nositelj (koordiniranih) aktivnosti na području suzbijanja korupcije i organiziranog kriminaliteta, po mišljenju Derenčinovića, jedna je od temeljnih pretpostavki učinkovitog suprotstavljanja korupciji. Mogućnost osnivanja posebnog državnog odvjetništva za kazneni progon počinitelja zakonom određenih kaznenih djela za čiji je progon Republika Hrvatska obvezana prema međunarodnom pravu proizlazila je iz članka 12. ZUSKOK-a. Iako autor ističe da bi bilo iluzorno očekivati da takvo jedno specijalizirano tijelo, ma kakvim nadležnostima raspolagalo, samo riješi problem korupcije u nekom društvu. Stoga bi njegova uloga ponajprije trebala biti koordinacijska u smislu objedinjavanja i optimalizacije svih antikorupcijskih instrumenata koji postoje u određenoj državi, Derenčinović, D., Mit(o) korupciji, Nocci, Zagreb, 2001., str. 271.

88 U nadležnost USKOK-a spada obavljanje poslova državnog odvjetništva za pojedina korupcijska kaznena djela i djela organiziranog kriminaliteta. Dakle, USKOK je ustrojen kao središnje tijelo koje će biti nositelj (koordiniranih) aktivnosti na području suzbijanja korupcije i organiziranog kriminaliteta, tako Kos, D.; Tripalo, D., Komentar Zakona o uredu za suzbijanje korupcije i organiziranog kriminaliteta, Narodne novine, Zagreb, 2001., str. 2.

89 Ova glava KZ-a obuhvaća skupinu kaznenih djela protiv spolnog zlostavljanja i iskorištavanja djeteta.

90 Ova glava KZ-a obuhvaća skupinu kaznenih djela protiv računalnih sustava, programa i podataka.

91 O mogućnosti proširenog oduzimanja imovinske koristi prema članku 82. stavak 2. KZ/97-a s osvrtom na neka poredbenopravna rješenja vidjeti Ivičević Karas, E., Kaznenopravno oduzimanje nezakonito stečene imovinske koristi, Hrvatski ljetopis za kazneno pravo i praksu, Zagreb, 2007., str. 687. do 680. 
instituta omogućena u odnosu na: a) kaznena djela iz nadležnosti USKOK-a, b) kaznena djela protiv spolnog zlostavljanja i iskorištavanja djeteta i c) kaznena djela protiv računalnih sustava, programa i podataka. ${ }^{92}$

U vezi s prethodnim, USKOK, kao posebno i samostalno pravosudno tijelo, nadležan je postupati u kaznenim predmetima taksativno u određenim kaznenim djelima specificiranim u članku 21. Zakona o Uredu za suzbijanje korupcije i organiziranog kriminala. ${ }^{93}$ Tom kogentnom odredbom ZUSKOK točno određuje za koja je kaznena djela nadležan postupati USKOK. Pritom navodeći prvo ona djela predviđena odredbama KZ/97-a (u stavku 1.), a zatim ona iz posebnog dijela KZ-a (u stavku 2.). Vezano uz pasivno podmićivanje, nadležnost USKOK-a obuhvaća sve kaznene inkriminacije pasivnog podmićivanja i u javnom (primanje mita iz članka 293. KZ-a i podmićivanje zastupnika iz članka 339. KZ-a) i u privatnom sektoru (primanje mita u gospodarskom poslovanju članak 252. KZ-a i primanje mita u postupku stečaja - članak 251. KZ-a). ${ }^{94}$ Stoga se može zaključiti da se institut proširenog oduzimanja imovinske koristi primjenjuje na sva kaznena djela pasivnog podmićivanja.

Prošireno oduzimanje imovinske koristi, prema regulaciji članka 78. KZa, podrazumijeva oduzimanje sve imovine osuđenika za koje on ne može učiniti vjerojatnim njezino podrijetlo, a nerazmjerna je njegovim zakonitim prihodima. Dakle, državni odvjetnik, za razliku od dotadašnjeg kaznenog materijalnog uređenja, nije dužan dokazivati da je imovina koju osuđenik ima ostvarena počinjenjem konkretnog kaznenog djela za koje ga se tereti, već je dostatno dokazati nerazmjer između okrivljenikove imovine i njegovih zakonitih primanja kako bi se pokazalo da je taj nerazmjer posljedica kriminalnog ponašanja tijekom dužeg razdoblja i da mu kazneno djelo koje mu se stavlja na teret ne predstavlja iznimku u ponašanju. ${ }^{95}$ Drukčije izneseno, institut proširenog oduzimanja imovinske koristi, kako je "postavljen" u pozitivnoj kazneno-materijalnoj regulaciji, pretpostavlja redukciju dokaznog standarda koji se primjenjuje pri utvrđivanju (ne) zakonitog podrijetla određene imovine te inverzije ili podjelu tereta dokazivanja (ne)zakonitog podrijetla određene imovine između tužitelja ili okrivljenika. ${ }^{96}$ Ovi zaključci proizlaze iz stipulacije odredbe članka 78. stavka 2.

92 Do stupanja na snagu Zakona o izmjenama i dopunama Kaznenog zakona (NN, br. 56/15. stupio na snagu 30. svibnja 2015.) primjena ovog instituta ticala se ekskluzivno kaznenih djela iz nadležnosti USKOK-a. Proširena primjena ovog instituta "posljedica" je implementacije Direktive 2014/42/EU, o čemu je bilo riječi u dijelu 2.4.

93 Zakon o Uredu za suzbijanje korupcije i organiziranog kriminala (NN, br. 76/09., 116/10., 145/10., 57/11., 136/12. i 148/13., u daljnjem tekstu: ZUSKOK - stupio je na snagu 1. srpnja 2009.).

94 U odnosu na ostala korupcijska kaznena djela i djela gospodarskog kriminaliteta pobliže vidjeti članak 21. ZUSKOK-a.

95 Ibidem bilj. 65. (Roksandić i dr., 2015.), str. 538.

96 Ibidem bilj. 65. (Roksandić i dr., 2015.).

97 O načelu vladavine prava kao jamstva legalne primjene proširenog oduzimanja imovinske koristi i konkretno o tomu je li redukcija dokaznog standarda suprotna temeljnim ustavnim i zakonskim načelima hrvatskoga pravnog sustava, ali i načelu prava na pravično (pošteno) suđenje iz čl. 6. st. 1. i 2. Konvencije (europske) za zaštitu ljudskih prava s protokolima 1, 4, 6, 7, 11, 12, 13 i 14, koja je u primjeni od 6. studenoga 1997. godine (NN-MU, br. 18/97., 6/99. - pročišćeni tekst, 8/99. - ispravak, 14/02., 13/03., 9/05., 1/06. i 2/10.) vidjeti Ibidem bilj. 65 
KZ-a, prema kojoj ako počinitelj kaznenog djela iz stavka 1. ovoga članka ima ili je imao imovinu koja je nerazmjerna njegovim zakonitim prihodima, pretpostavlja se da ta imovina predstavlja imovinsku korist od kaznenog djela, osim ako počinitelj učini vjerojatnim da je njezino podrijetlo zakonito. S tim u vezi, ako je imovinska korist od kaznenog djela sjedinjena s imovinom stečenom zakonito, ukupna imovina bit će predmet oduzimanja do procijenjene vrijednosti imovinske koristi. $\mathrm{Na}$ isti način i u istom omjeru oduzet će se i korist koja je dobivena od imovine u koju je zakonita imovina sjedinjena s imovinskom korišću od kaznenog djela (članak 78. stavak 3. KZ-a). Izneseni zaključci proizlazili bi dijelom i iz novije kaznene prakse Vrhovnog suda Republike Hrvatske ${ }^{98}$, koji je, u odluci poslovni broj I KžUs-56/153 od 2. veljače 2016. godine ${ }^{99}$, zauzeo pravno shvaćanje po kojem odredba članka 78. stavka 2. KZ-a omogućuje oduzimanje imovinske koristi koja nije pribavljena konkretnim inkriminiranim kaznenim djelima, već se radi o koristi za koju okrivljenik nema pokriće u zakonitim prihodima. ${ }^{100} \mathrm{Na}$ kraju, u ovom dijelu, primjećuje se da je kod ovoga kaznenog instituta teret dokaza podijeljen između državnog odvjetnika i okrivljenika pritom je intencija zakonodavca očito bila olakšati "aktivnoj strani u postupku" oduzimanje nezakonito stečene imovine kako bi se zaštitio opći interes i uspostavilo stanje prije počinjenja kaznenog djela. ${ }^{101}{ }^{102}$ Međutim, da bi uopće dokazao nerazmjer, državni odvjetnik ipak je dužan tijekom istrage provesti opsežnu "financijsku" istragu, u čemu mu bitno može pomoći i Porezna uprava ${ }^{103}$, odnosno tzv. porezni USKOK ili, preciznije, Samostalni sektor za otkrivanje poreznih prijevara

(Roksandić i dr., 2015.), str. 539-540.

98 U daljnjem tekstu: Vrhovni sud.

99 Odluka dostupna na: https://sudskapraksa.csp.vsrh.hr/

100 Iz obrazloženja odluke broj I KžUs-56/15-3 od 2. 2. 2016.: “... Prema tome, evidentno je da su u konkretnom slučaju ostvarene sve zakonske pretpostavke za tzv. prošireno oduzimanje imovinske koristi iz članka 78. stavak 2. KZ/11 koji propisuje mogućnost oduzimanja imovinske koristi koja nije pribavljena konkretnim inkriminiranim kaznenim djelima, već se radi o koristi za koju okrivljenik nema pokrića u zakonitim prihodima. Ovaj zaključak utemeljen je i na činjenici da je ovaj sud svojim rješenjem br. I Kž-Us 144/14 od 20. siječnja 2015. već pravomoćno primijenio kategoriju proširenog oduzimanja imovinske koristi od okrivljenika u smislu odredbe članka 78. stavak 2 . KZ/11, te zauzeo stav da postoji očiti nesrazmjer između imovine okrivljenika koju posjeduje i njegovih zakonitih prihoda....".

101 Slično ibidem bilj. 65. (Roksandić i dr., 2015.), str. 541.

102 Valja istaknuti da je čl. 6. Zakonom o izmjenama i dopunama Zakona o Uredu za suzbijanje korupcije i organiziranog kriminaliteta (NN, br. 148/13 - stupio na snagu 15. prosinca 2013.) promijenjen sastav USKOKA, tako da za druge odjele, tajništva i pratećih službi, osnovan u normativnom smislu "Odjel za istraživanje imovinske koristi stečene kaznenim djelom". Praktično sagledavano ovaj, ali i svaki drugi odjel odnosno pravosudno tijelo, treba "oživiti" i osigurati mu kadrovske, financijske i druge kapacitete dostatne za učinkovit rad.

103 Naime, usporedba i prikupljanje podataka bitnih za oporezivanje u nadležnosti je Porezne uprave prema čl. 88. i 89. Zakona o porezu na dohodak (NN, br. 115/16). Isto bilo predviđeno i odredbama čl. 63. Zakona o porezu na dohodak (NN, br. 177/04, 73/08, 80/10, 114/11, 22/12, $144 / 12,43 / 13,120 / 13,125 / 13,148 / 13,83 / 14,143 / 14,136 / 15$ i 115/16). 
(SSOPP104, 105, 106, 107).

KZ, uređujući institut proširenog oduzimanja imovinske koristi, nameće obvezu kaznenom sudu da u slučajevima članka 78. stavka 2. i 3., oduzme imovinsku korist i od člana obitelji ${ }^{108}$ bez obzira po kojem pravnom temelju se kod njega nalazi i neovisno o tome živi li u zajedničkom kućanstvu s počiniteljem (članak 78. stavak 4. KZ-a), ali i od druge osobe bez obzira po kojem pravnom temelju je stečena ako ta osoba ne učini vjerojatnim da je korist stekla u dobroj vjeri i po razumnoj cijeni (članak 78. stavak 5. KZ-a). U tumačenju ovih normi, Vrhovni sud ${ }^{109}$ zaključio je da KZ, u članku 78. stavku 4. i 5., određuje da će se ta imovinska korist oduzeti od člana obitelji (značenje izraza "član obitelji" - članak 87. stavak 8 . KZ/11, među ostalim bračni drug i brat)

104 Pravni temelj za ustroj ovoga samostalnog i neovisnog tijela proizlazi iz čl. 1. Uredbe o izmjenama i dopunama Uredbe o unutarnjem ustrojstvu Ministarstva financija (NN, br. 134/14 - stupila na snagu 25. 11. 2014., u daljnjem tekstu: Uredba o unutarnjem ustrojstvu Ministarstva financija).

105 U djelokrug rada SSOPP-a, prema čl. 25.a st. 1. Uredbe o unutarnjem ustrojstvu Ministarstva financija, spadaju ovi poslovi: prikupljanje, kontrola, analitička obrada i razmjena podataka radi otkrivanja rizičnih poreznih obveznika koji sudjeluju u organiziranim poreznim prijevarama koje imaju za posljedicu velike porezne utaje, osobito u međunarodnim prijevarama iz područja PDV-a (kružne i lančane transakcije, fiktivne isporuke i sl.); otkrivanje fizičkih osoba koje posjeduju imovinu značajne vrijednosti, a koju su stekle nezakonito, bez pokrića u zakonito ostvarenim primitcima te otkrivanja imovine poreznih dužnika koja nije obuhvaćena mjerama ovrhe ili koja je u cilju onemogućavanja naplate poreznog duga prenesena na druge osobe; suradnja s tijelima kaznenog progona u otkrivanju kaznenih djela povezanih s gospodarskim kriminalitetom i utajama poreza i drugih javnih davanja; dostava nadležnim tijelima prikupljenih i obrađenih podataka radi pokretanja poreznih, prekršajnih i kaznenih postupaka; po potrebi koordinacija rada nadzornih tijela u daljnjem postupanju i operativnog uključivanja u postupke; razmjena podataka i dokumentacije sa stranim jedinicama za suzbijanje poreznih utaja; praćenje propisa, pravne stečevine i sudske prakse Europske unije iz područja za koje je ustrojen; te druge zadaće bitne za razvoj preventivnog sustava i sprječavanje poreznih utaja. Unutar SSOPP-a ustrojene su zasebne tri službe: 1. Služba za otkrivanje organiziranih prijevara, 2. Služba za provjeru imovine fizičkih i poreznih dužnika i 3. Služba za suradnju s tijelima kaznenog progona (članak 25.a stavak 2. Uredbe o unutarnjem ustrojstvu Ministarstva financija).

106 Važno je naglasiti da je postupak proširenog oduzimanja imovinske koristi reguliran specijalnim odredbama ZOPOIK-a i općenitim odredbama ZKP-a, a osiguranje (proširenog) oduzimanja imovinske koristi (privremenim mjerama i dr.) u odnosu na dio iz nadležnosti USKOK-a, pored ZKP-om koji sadrži općenite postupovne norme i odredbama dvaju posebnih zakona: ZUSKOK-a (Glava IV. - članak 50. do 61.) i ZOPOIK-a. S tim u vezi, prema čl. 34. st. 1. ZOPOIK-a ovaj Zakon primjenjuje se u postupku za kaznena djela iz članka 21. ZUSKOK-a, ako drukčije nije propisano tim zakonom.

107 O dokazivanju postojanja okolnosti za određivanje privremenih mjera u vezi s oduzimanjem imovinske koristi vidjeti odluku Vrhovnog suda poslovni broj i KžUs-112/13-4 od 1. listopada 2014. - dostupna na: https://sudskapraksa.csp.vsrh.hr/.

$108 \mathrm{KZ}$, u čl. 87. st. 8., pod "članom obitelji” podrazumijeva bračnog ili izvanbračnog druga, životnog partnera ili neformalnog životnog partnera, njihovu zajedničku djecu te djecu svakog od njih, srodnika po krvi u ravnoj lozi, srodnika u pobočnoj lozi zaključno do trećeg stupnja, srodnike po tazbini do zaključno drugog stupnja, posvojitelja i posvojenika.

109 U presudi poslovni broj: I KžUs-144/14-4 od 20. veljače 2015. - dostupna na: https:// sudskapraksa.csp.vsrh.hr/. 
bez obzira na to po kojem pravnom temelju se kod njega nalazi i neovisno o tome živi li u zajedničkom kućanstvu s počiniteljem, kao i od druge osobe bez obzira po kojem pravnom temelju je stečena ako ta osoba ne učini vjerojatnim da je korist stekla u dobroj vjeri i po razumnoj cijeni. ${ }^{110}$

Štoviše, u članku 78. stavku 6., KZ predviđa i poseban slučaj oduzimanja imovinske koristi i u nasljeđivanju. Prema toj zakonskoj odredbi ako osoba protiv koje je pokrenut kazneni postupak umre, imovinska korist ostvarena protupravnom radnjom može se oduzeti od njezinih sljednika u postupku propisanom posebnim zakonom.

U izloženom, analizom odredbi članka 78. KZ-a, a cijeneći regulaciju članka 21. ZUSKOK-a, KZ nije omogućio primjenu instituta proširenog oduzimanja imovinske koristi u domaćem pravnom sustavu na sva kaznena djela. Primjena ovog instituta nije omogućena niti na sva korupcijska kaznena djela iz kataloga inkriminacija KZ-a. ${ }^{111}$

Unatoč zakonskoj mogućnosti primjene i izloženog (i u dijelu manjkavoj) regulaciji ovog instituta, nužno je međuinstitucionalnom suradnjom urediti $i$ druga područja unutar države kako bi se počiniteljima, poglavito korupcijskih kaznenih djela i organiziranog kriminala, u praksi onemogućilo ili otežalo skrivanje i prisvajanje protupravno stečene imovine i njezino inkorporiranje u "legalne tijekove novca". ${ }^{112}$

\section{ZAKLJUČNA RAZMATRANJA}

Korupcijska kaznena djela i ona koja uključuju organizirani kriminal predstavljaju jedan od najznačajnijih izvora ugrožavanja nacionalne sigurnosti u uređenim zemljama, kojima pripada i Hrvatska. Stoga, ne čudi da je zakonodavac u temeljne odredbe zakonskog teksta ugradio, kao osnovno kazneno načelo, i oduzimanje imovinske koristi. Naime, oduzimanje imovinske koristi, a posebno institut proširenog oduzimanja imovinske koristi što je novina kaznene materijalne regulacije, predstavlja

110 Sud je tada, među ostalim, zaključio: “...Naime, odredba članka 78. stavak 2. KZ/11 uređuje tzv. prošireno oduzimanje imovinske koristi na način da ako počinitelj kaznenog djela iz nadležnosti USKOK-a ima ili je imao imovinu koja je nerazmjerna njegovim zakonitim prihodima, pretpostavlja se da ta imovina predstavlja imovinsku korist od kaznenog djela, osim ako počinitelj učini vjerojatnim da je njezino podrijetlo zakonito. U stavku 4. i 5. iste norme je određeno da će se ta imovinska korist oduzeti od člana obitelji (značenje izraza "član obitelji" - članak 87. stavak 8 . KZ/11, među ostalim bračni drug i brat) bez obzira po kojem pravnom temelju se kod njega nalazi i neovisno o tome živi li u zajedničkom kućanstvu s počiniteljem, kao i od druge osobe bez obzira po kojem pravnom temelju je stečena ako ta osoba ne učini vjerojatnim da je korist stekla u dobroj vjeri i po razumnoj cijeni. S tim u vezi, valja odmah dodati da je shodno odredbama članka 3. stavak 1. točka 2., 4. i 6. c) ZOPOIK-a (koji korespondira sa spomenutim materijalno-pravnim propisima) privremene mjere osiguranja moguće odrediti na svim stvarima i pravima koje mogu biti predmet ovrhe, a koje su u vlasništvu, posjedu ili pod kontrolom okrivljenika ili povezane osobe. Žalitelj je upisan kao jedini vlasnik nekretnina, pa nema mjesta određivanju privremene mjere samo na polovici nekretnina kako se sugerira $u$ žalbi....".

111 Primjerice na (korupcijsko) kazneno djelo prijevare u gospodarskom poslovanju iz čl. 245. KZa.

112 Slično ibidem, bilj. 65. (Roksandić i dr., 2015.), str. 534. 
jednu od ključnih kaznenih mjera u borbi i suzbijanju korupcijskih kaznenih djela, u koje, kao tipično, spada i pasivno podmićivanje.

Analizom i raščlambom izložene međunarodne pravne stečevine, KZ, u odnosu na oduzimanje imovinske koristi, svakako predstavlja legislativni "korak naprijed". Ovo stoga što je njime postignuto "dodatno" usklađivanje domaće regulacije u vezi promatranog instituta radi učinkovitije borbe i suzbijanja korupcijskih kaznenih djela.

Međutim, mišljenja smo da pozitivno kazneno materijalno uređenje instituta (proširenog) oduzimanja imovinske koristi opterećuje u određenim segmentima neusklađenost normativa, što je otežalo primjenu propisa u kaznenoj grani sudovanja, a što može dovesti i do neujednačenog tumačenja i primjene prava odnosno nejedinstvene prakse. Normativna neusklađenost ponajprije se odnosi na pojmovno određenje imovine i imovinske koristi.

Uz to, postoje neki važni segmenti u regulaciji koji zahtijevaju dodatnu analizu i "noveliranje" kako bi se postojeća zakonska regulacija uskladila s međunarodnom pravnom stečevinom po pitanju instituta proširenog oduzimanja imovinske koristi. To se ponajprije odnosi na krug kaznenih djela na koje se može primijeniti navedeni institut. Naime, KZ, suprotno međunarodnoj pravnoj stečevini, posebice sadržaju Direktive 2014/42/EU, nije omogućio primjenu ovoga instituta na sva korupcijska kaznena djela iz postojećeg kataloga inkriminacija i u javnom i u privatnom "sektoru".

Uklanjanjem iznesenih normativnih nedostataka, s jedne strane, domaći sustav (proširenog) oduzimanja imovinske koristi mogao bi postati primjer kvalitetne kaznene materijalne regulacije, a, s druge time bi se spriječila "potencijalna" arbitrarnost, neodgovornost i samovolja u primjeni toga instituta u praksi.

\section{LITERATURA}

Knjige i radovi:

1. Bačić, F., Korupcija i antikorupcijsko kazneno pravo, Hrvatski ljetopis za kazneno pravo i praksu, Zagreb, 2000.,

2. Bačić, F., Kazneno pravo, Opći dio, Zagreb, 1998.,

3. Datzer, D.; Vujović, S., Kaznena politika za korupcijska kaznena djela na području kantona Sarajevo, Kriminologija i socijalna integracija, 2013.,

4. Derenčinović, D., Kaznenopravni aspekti korupcije s elementom inozemnosti, Hrvatski ljetopis za kazneno pravo i praksu, Zagreb, 1999.,

5. Derenčinović, D., Mit(o) korupciji, Nocci, Zagreb, 2001.,

6. Garačić, A., Kako prečeste izmjene kaznenih zakona utječu na pravnu sigurnost, Informator, br. 6401, Zagreb, 2016.,

7. Garačić, A., Kazneni zakon u sudskoj praksi, Naklada Zadro, Zagreb, 2001.,

8. Ivičević, E., Oduzimanje imovinske koristi stečene kaznenim djelom, Hrvatsko udruženje za kaznene znanosti i praksu Ministarstva unutarnjih poslova Republike Hrvatske, Zagreb, 2004.,

9. Ivičević Karas, E., Zakon o postupku oduzimanja imovinske koristi ostvarene kaznenim djelom i prekršajem: neka otvorena pitanja i moguća rješenja, Hrvatski ljetopis za kazneno pravo i praksu, Zagreb, 2011.,

10. Ivičević Karas, E., Kaznenopravno oduzimanje nezakonito stečene imovinske koristi, Hrvatski ljetopis za kazneno pravo i praksu, Zagreb, 2007.,

11. Kaleb, Z., Novo uređenje instituta oduzimanja imovinske koristi prema noveli Kaznenog 
zakona, Hrvatski ljetopis za kazneno pravo i praksu, Zagreb, 2003.,

12. Kos, D., Problematika oduzimanja imovinske koristi, Hrvatski ljetopis za kazneno pravo i praksu, Zagreb, 1998.,

13. Kos, D.; Tripalo, D., Komentar Zakona o uredu za suzbijanje korupcije i organiziranog kriminaliteta, Narodne novine, Zagreb, 2001.,

14. Kregar, J., Korupcija, Financijska praksa, Zagreb, 1997.,

15. Mrčela, M., Pravni i praktični aspekti oduzimanja imovinske koristi u kaznenom postupku, Policija i sigurnost, Zagreb, 1999.,

16. Novosel, D., Financijske istrage i progon počinitelja gospodarskog kriminaliteta, Hrvatski ljetopis za kazneno pravo i praksu, Zagreb, 2007.,

17. Obidario, S., Transnational Corruptionand Corporations: Regulating Briberythrough Corporate Liability, Englan i USA: Ashgate Publishing Limited, 2013.,

18. Pavlović, Š., Kazneni zakon, Libertin naklada, Rijeka, 2012.,

19. Roksandić Vidlička, S.; Šamota, Galjer, M., Političko-gospodarski kriminalitet i prošireno oduzimanje imovinske koristi: Quo vadis, Hrvatska?, Hrvatski ljetopis za kazneno pravo i praksu, Zagreb, 2015.,

20. Saračević, A., Korupcijska kaznena djela, Hrvatska pravna revija, Zagreb, 2008.,

21. Staničić, T., Pravna priroda instituta oduzimanja imovinske koristi i njegovo mjesto u krivičnom pravu, Zbornik radova Pravnog fakulteta u Splitu, Split, 1979

22. Horvatić, Ž.; Novoselec, P., Kazneno pravo - Opći dio, Zagreb, 2001.,

Vrela s Interneta:

1. eur-lex.europa.eu

2. dana.europa.eu/eli/dir2014/42/oj/hrv/pdfa1a

3. www.sabor.hr/Default.aspx?art=41259

4. www.vsrh.hr

5. https://sudskapraksa.csp.vsrh.hr/

Sudska praksa:

1. presuda Vrhovnog suda Republike Hrvatske I Kž-Us 144/14 od 20. siječnja 2015.,

2. presuda Vrhovnog suda Republike Hrvatske Kž Us-112/13-4 od 1. listopada 2014.,

3. presuda Vrhovnog suda Republike Hrvatske I Kž Us-144/14-4 od 20. veljače 2015.. 
Summary

\section{CONFISCATION OF PECUNIARY GAIN IN THE CONTEXT OF INTERNATIONAL REGULATIONS AND COMBATING BRIBERY}

Appropriate reaction on bribery criminal offenses is of a great importance for every legal order. The success of this reaction, and of the confiscation of pecuniary gain, as its very important aspect, affects the overall political and economic development of a country. Effective (extended) confiscation of pecuniary gain is particularly important when it comes to criminal offenses of (passive) bribery. These criminal offenses are based on "corruption agreement" that aims to "satisfy" certain (material) interests and benefits for both parties of the "agreement".

Appropriate legal reaction on bribery criminal offenses, as well sa the confiscation of pecuniary gain by these criminal offense, depends on the attitudes of a certain society and its "establishment".

This paper deals with (extended) confiscation of pecuniary gain acquired by criminal offense, in the context of bribery offenses, by presenting domestic and international regulations and case law, and analyzing compliance of domestic regulations with international regulations.

Keywords: corruption, bribery, assets, pecuniary gain, pecuniary gain acquired by a criminal offense, confiscation of pecuniary gain, extended confiscation of pecuniary gain.

\section{Zusammenfassung}

\section{BESCHLAGNAHME VON VERMÖGENSGEWINN IM RAHMEN INTERNATIONALER REGELUNGEN UND BESTECHUNGSBEKÄMPFUNG}

Eine angemessene Reaktion auf Bestechungsdelikte ist für jede Rechtsordnung von großer Bedeutung. Der Erfolg dieser Reaktion und die Beschlagnahme des finanziellen Gewinns als ihrem sehr wichtigen Aspekt wirkt sich auf die gesamte politische und wirtschaftliche Entwicklung eines Landes aus. Eine wirksame (verlängerte) Beschlagnahme des Vermögensgewinns ist besonders wichtig, wenn es sich um Straftaten von (passiver) Bestechung handelt. Diese Straftaten beruhen auf dem "Korruptionsvertrag", der bestimmte (materielle) Interessen und Vorteile für beide Teile des "Vertrags" "befriedigen" soll.

Eine entsprechende rechtliche Reaktion auf Bestechungsdelikte sowie die Einziehung von Vermögensgewinnen durch diese Straftaten hängt von den Einstellungen einer bestimmten Gesellschaft und ihrer "Niederlassung" ab. 
DieserArtikel befasstsichmitdem(erweiterten)Entzug von Vermögensgewinnen, die durch Straftat im Rahmen von Bestechungsdelikten, durch Vorlage nationaler und internationaler Regelungen und der Rechtsprechung erworben wurden, und analysiert die Einhaltung nationaler mit internationalen Regelungen.

Schlüsselwörter: Korruption, Bestechung, Vermögenswerte, Vermögensgewinn, durch eine Straftat erworbener Gewinn, Beschlagnahme des Vermögensgewinns, erweiterter Entzug des Vermögensgewinns.

Riassunto

\section{LA CONFISCA DEL VANTAGGIO ECONOMICO NELL'AMBITO DELLA REGOLAMENTAZIONE INTERNAZIONALE E LA LOTTA ALLA CORRUZIONE}

La reazione giuspenalistica ai reati di corruzione è di fondamentale importanza per il funzionamento di qualsiasi sistema giuridico. Dalla buona riuscita di tale reazione, in particolare di un suo fondamentale segmento - quale è la confisca patrimoniale -, dipende l'intero sviluppo politico ed economico di ogni singolo paese. L'efficace applicazione della misura della confisca patrimoniale s'è dimostrata importante nella prassi specialmente con riguardo ai reati di corruzione passiva. Precisamente, di regola, si tratta di reati che sottintendono la creazione di una "alleanza corruttiva" nella quale entrambe le parti possono ritenersi "soddisfatte", poiché realizzano determinati vantaggi patrimoniali.

Quale sarà la reazione giuspenalistica nei confronti dei corruttori dipende dalla presa di posizione di ciascuna singola società civile, ovvero di chi ivi in qual momento sia al potere. Dalla loro concezione dipende, infatti, la reazione giuspenalistica nei confronti dei corruttori dal punto di vista della confisca patrimoniale nella normativa penale.

A sostegno del dibattitto dottrinale nel lavoro si analizza la misura penale della confisca dei beni patrimoniali nell'ambito della regolamentazione internazionale ai fini della lotta alla corruzione, con particolare attenzione alla recente prassi giurisprudenziale domestica. Ancora, viene posto l'accento sulla rassegna della normativa nazionale ed internazionale circa la c.d. confisca allargata dei beni patrimoniali. Altresì, in chiusura, con metodo comparato, viene offerta un'analisi della difformità della disciplina giuridica sostanziale di diritto interno rispetto alle soluzioni giuridiche prospettate sul piano internazionale e concernenti la questione in oggetto.

Parole chiave: corruzione, patrimonio, vantaggio patrimoniale, vantaggio realizzato mediante reato, confisca di beni patrimoniali, confisca allargata di beni patrimoniali. 
